\title{
Evaluation of Protection of Critical Infrastructure in Nigeria. A Case Study of Protection of Power Facilities in Abuja
}

\author{
Saladin Quadri Adigun \\ National Open University of Nigeria, \\ Special Study Centre, Civil Defence Academy Sauka, Abuja, Nigeria
}

Doi: 10.19044/esj.2018.v14n11p80 URL:http://dx.doi.org/10.19044/esj.2018.v14n11p80

\begin{abstract}
This research work investigated the protection of critical infrastructure in Nigeria with special attention to electric power infrastructure within Federal Capital Territory (FCT), Abuja. The study was guided by six research questions and the instrument employed for the research was titled 'Evaluation of the Effectiveness of Protection of Critical Infrastructure' (EEPCI). The study was carried out among the consumers of electricity in three of the six Area Councils, the security personnel employed to guard as well as the workers of the power facilities called Abuja Electricity Distribution Company (AEDC) and Transmission Company of Nigeria (TCN) in the capital territory. The entire population of the study was 3,750 and this cut across the strata of the stakeholders in power industry. The data gathered were analyzed by the use of frequency, percentages and statistical mean distribution technique. Findings from the study showed that the existing protection techniques are weak, unassertive and the power companies are slow to mitigating effects of attacks on their facilities. Based on the findings, the researcher recommended that policies and equipment protection strategies be utilized by the power companies and the government. The study laid emphasis on establishment of community anti-crime group and provision of free toll hotline for emergency purposes. Furthermore, the penalty for damages to power facilities was recommended to be stiffer and the security should be empowered to excel in their profession.
\end{abstract}

Keywords: Protection; effectiveness, critical infrastructure; evaluation, power facilities; Electricity Company

\section{Introduction}

Effective protection of power infrastructural facilities is panacea to nation's security, economic vitality, public health and safety. The central goal 
of effective protection of critical infrastructural facilities is therefore to secure, prevent, neutralize or mitigate the effects of accidental or deliberate efforts by terrorists plan to destroy, incapacitate or exploit the facilities. When these infrastructural facilities are safe and effective then development is assured. Ola, (2010) was of the opinion that sustainable development is attainable with solid infrastructural base. Availability of critical infrastructure for public usage is susceptible to natural and man-made attacks. Badiora and Obadiora (2011) were of the opinion that deficit in supply of infrastructure is actually worsened by man-made activities and there is need to plan for protection.

Protection of infrastructure may include building resiliency around the facility, installing security systems and initiating counter measures (Janes 2014). In the global United Nations Development Programmes' (UNDP) Human Development Index ranking (HDI) of 2004, 2005, 2006 and 2008, the National Bureau of Statistics (NBS) ranked Nigeria low because of infrastructure deficit. The establishment of Nigeria Security and Civil Defence Corps (NSCDC) was therefore one of the measures to protect critical national assets and infrastructure (CNAI) and was supported by NSCDC Act 2003 and amended NSCDC Act of 2007. The Act therefore is a confirmation about the sincerity and commitment of the Federal Government to protect critical national assets and infrastructure (CNAI) in Nigeria.

Critical infrastructure on its own may include communications; emergency services; energy sector; dams; food; public services; industry; health; transport; gas; public communications, radio and television; commercial facilities; chemical and nuclear sectors.

Many facilities were classified as critical infrastructure by the Federal Government of Nigeria through the office of National Security Adviser (ONSA) to the President. Going by definition, the word "critical" refers to infrastructure which, if disabled or destroyed, would result in catastrophic and far reaching damage. According to European Commission, critical infrastructure was defined as an "asset or system which is essential for the maintenance of vital societal functions". The Canadian Organization for Economic and Cooperation Development (OECD) defined critical infrastructure protection has cyclical process incorporating prevention, detection, mitigation, response and recovery (OECD 2008). According to the 'Risk Management Approach' of the OECD, the best protection result is gotten when surveillance and access management to the facility is adequately implemented. At this juncture, a brief mention of the concept of protection involving crime prevention through environmental design (CPTED) has employed in this research should be explained. The concept according to (Paulsen \& Robinson, 2004) involve hardening of critical infrastructure targets, deterrence, punishment of accused persons, better illumination and lighting up of targets of vandalism. Similarly, 
knowing your neighbour and the use of surveillance to protect vulnerable targets as suggested by Laurence (2011) was equally applied.

The fact that energy sector has domineering influence to upshot the deliverables from all other critical infrastructure accounts for it vulnerability; and it is important to note that production and supply of electrical energy relies on complex system which includes but not limited to gas pipelines, flow stations and refineries where Oil and Gas is the source of fuel. When it comes to transmission of the generated energy, attention is shifted to electrical energy pylons, tower member, Injection stations and substations.

Electrical power facility as a critical infrastructure in Nigeria was divided into Power Generating, Transmission and Distribution sections. Although there are many Steam-Power Generating Stations, Gas-Power Generating Stations and Hydro Power Stations, but there exist one transmission company known as Transmission Company of Nigeria (TCN) and eleven Power Distribution Companies in the country. All these companies are privately owned except the Transmission Company of Nigeria (TCN).

In protecting critical infrastructure, the responsibility for setting goals rests primarily with the government, but the implementation of steps to reduce the vulnerability of privately owned and corporate assets depends primarily on private-sector knowledge and action.

\section{Statement of the problem}

Electricity is the most vital of the critical infrastructure and key resources that support our society. It is the over-all cure for economic helplessness and solution to security of businesses, properties, public and private life. Electricity is so important but its generation and transmission in Nigeria cannot be guaranteed for the fact that it is constantly under attack while its distribution is regularly vandalized. By the same token when considering the users' end, energy theft is continuously being witnessed and all these put together give rise to irregular power supply, jeopardizing ease of doing business and the concomitant effect is hardship and inconveniences to the entire populace. The purpose of this study therefore is to investigate the energy sector as a subdivision of critical national assets and infrastructure and evaluate how it is being protected in Nigeria.

\section{Specific Objective}

The significant influence of energy sector on all other sectors makes it the most vulnerable subdivision of critical infrastructure, in the light of this, the core objective of this study is to investigate and evaluate the effectiveness of protection of electrical power facilities in Federal Capital Territory (FCT) Abuja.

\section{Objectives of the Study}

The main objectives of the study are examined under the followings: 
1. To investigate the method of protection being used and the effectiveness of the protection technique employed by Electricity Power Company in FCT.

2. To ascertain the level of support of the host community in protection of power facilities within their environment.

3. To examine the level of commitment of the staff of Electricity Power Company toward securing the company's facilities in FCT.

4. To discover the effectiveness of the retributive laws and court verdicts meant to protect power facilities from vandalism.

5. To determine the level of preparedness of FCT security personnel in mitigating the effects of attacks on power facilities?

6. To investigate the level of protection against vandalism in government owned Transmission Company.

\section{Research Questions}

The study was guided by the following research questions:

1. How effective is the protection technique employed to safe guard power facilities of the Power Companies in FCT?

2. Are the community people in FCT willing to support in protecting power facilities?

3. How much support do the staff of electricity Power Company offer to the protection of power facilities in FCT?

4. Are the court verdicts, laws and terms of convictions helpful in curtailing attacks on power facilities in FCT?

5. What is the level of preparedness of security personnel to mitigate the effect of attacks on power facilities in FCT?

6. How effective is the existing vandalism protection technique on the power transmission facilities within FCT?

\section{Research Methodology}

The researcher employed a descriptive research method to analyze and solve the research problems (Kothari 2004). The principles of Crime Prevention through Environmental Design (CPTED) as suggested by David (2011) was adopted and reflected in the composition of the questionnaires. Subheadings under research methodology are hereby explained in the order below: Population of the Study, Sampling and Sampling Procedure, and Research Instrument. Others are discussed under Findings, Discussions and Recommendations.

\section{Population of the Study}

The respondents of this study were consumers and power company workers from six power distribution Business Areas of coverage, three Injection Sub Stations, three Distribution Cash offices, and one Regional office. Others are two Private Guard companies and armed security personnel on guard. 


\section{Sampling and Sampling Procedure}

Random sampling method was employed in selecting the respondents to ease the complexity of dealing with over three thousand participants. For the purpose of this study, there were three (3) zones called area councils and from each there were five (5) respondents who were randomly selected from the power company distribution and transmission offices, ten (10) consumers of electricity supply from each area council and ten (10) respondents from security arena were selected from each of the three (3) Area Councils identified for this project. The gathered data were collated, statistically analyzed and interpreted.

\section{Research Instrument}

The research instrument used for collection of data in this study was 'Evaluation of the Effectiveness of Protection of Critical Infrastructure' (EEPCI). The research instrument employed was questionnaire having four sections ' $A$ ', 'B', 'C', and ' $D$ '. There were fifty (50) numbers of structured questionnaires in all the sections. It should be noted that section ' $\mathrm{B}$ ' was further divided into parts 1,2,3,4 and 5 .

\section{Findings and Discussion}

\section{Research Question One}

How effective is the protection technique employed to safe guard the power facilities of Power Companies in FCT working?

Table 4.3.1 Responses on protection techniques in FCT

\begin{tabular}{|c|c|c|c|c|c|}
\hline \multirow[t]{2}{*}{$\mathbf{S} / \mathbf{N}$} & \multirow[t]{2}{*}{ Questions } & \multicolumn{2}{|c|}{$\begin{array}{c}\text { Total } \\
\text { Responses }\end{array}$} & \multicolumn{2}{|c|}{$\begin{array}{l}\text { Percentage } \\
\text { Responses }\end{array}$} \\
\hline & & Yes & No & $\begin{array}{c}\% \\
\text { Yes }\end{array}$ & $\%$ No \\
\hline 1 & $\begin{array}{l}\text { Is it true that fencing and restricting access } \\
\text { to power facilities within FCT is protecting } \\
\text { this equipment? }\end{array}$ & 48 & 2 & 96 & 4 \\
\hline 2 & $\begin{array}{l}\text { Do you agree that there exists surveillance } \\
\text { equipment on power facilities in your area? }\end{array}$ & 9 & 41 & 18 & 82 \\
\hline 3 & $\begin{array}{l}\text { Do you agree that there is good illumination } \\
\text { surrounding power facilities located in your area? }\end{array}$ & 23 & 27 & 46 & 54 \\
\hline 4 & $\begin{array}{c}\text { Is it true that armed security personnel are } \\
\text { on ground to protect power facilities in your } \\
\text { area? }\end{array}$ & 9 & 41 & 18 & 82 \\
\hline 5 & $\begin{array}{c}\text { Do you agree that the electricity power equipment in } \\
\text { your area is covered by Insurance bond? }\end{array}$ & 13 & 36 & 26 & 74 \\
\hline \multirow[t]{2}{*}{6} & $\begin{array}{l}\text { Will you agree that there are private vigilante } \\
\text { security personnel protecting power facilities in your } \\
\text { area? }\end{array}$ & 17 & 33 & 34 & 66 \\
\hline & \multicolumn{3}{|l|}{ Aggregate percentage in support } & 39.67 & \\
\hline
\end{tabular}

Source: Field survey 2018 
Using the above table 4.3.1 and the corresponding graphical representation below for interpretation, the protection technique pattern showed that fencing and access control to power facilities in FCT is reasonably high with $96 \%$ but the use of surveillance equipment is extremely poor having 18\%. Lighting and illumination around power facilities in FCT was found to be poor with $46 \%$ while the presence of security to guard the equipment is equally low for optimum protection. The result equally identified quite low level of private security personnel involvement at the community base stations in provision of secondary protection around power facilities. Generally therefore, the existing protection technique around power facilities in FCT is about $39.67 \%$ which is grossly inadequate.

Graph 4.3.1 Responses on protection technique pattern in FCT

\begin{tabular}{|c|c|c|c|}
\hline S/N & A & B \% & C \% \\
\hline 1 & $\begin{array}{c}\text { Fencing found around many } \\
\text { power facilities }\end{array}$ & 96 & 4 \\
\hline 2 & $\begin{array}{c}\text { Few surveillance Equipment in } \\
\text { few places }\end{array}$ & 18 & 82 \\
\hline 3 & $\begin{array}{c}\text { Illumination is poor around } \\
\text { power facilities }\end{array}$ & 46 & 54 \\
\hline 4 & $\begin{array}{c}\text { Few security personnel available } \\
\text { around facilities }\end{array}$ & 18 & 82 \\
\hline 5 & $\begin{array}{c}\text { Low Insurance cover on power } \\
\text { facilities }\end{array}$ & 26 & 74 \\
\hline 6 & $\begin{array}{c}\text { Private security considered in } \\
\text { few places }\end{array}$ & 34 & 66 \\
\hline
\end{tabular}

Private security considered in few places

Low Insurance cover on power facilities

Few security personnel available around facilities

Illumination is poor around power facilities

Few surveillance Equipment in few places

Fencing found around many power facilities

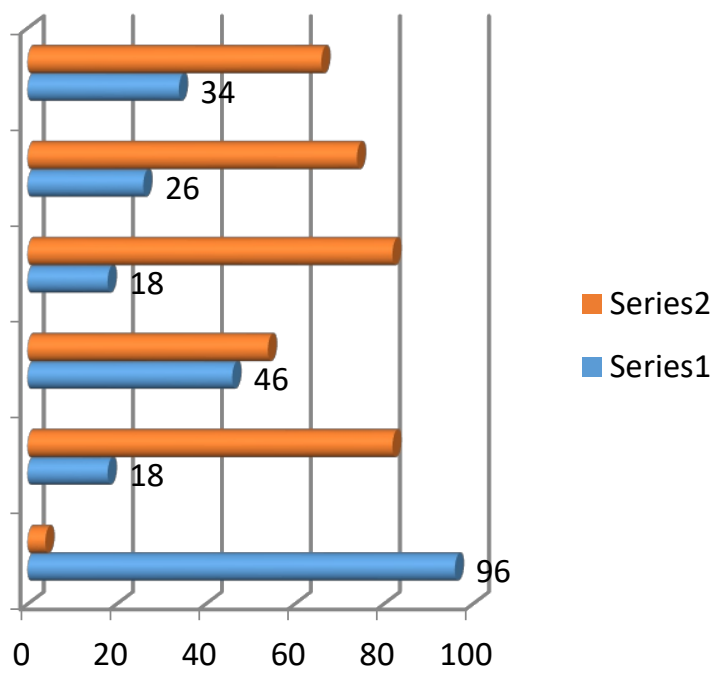




\section{Research Question Two}

Are the community people in FCT willing to support in protecting power facilities?

Table 4.3.2 Community protection support level in FCT

\begin{tabular}{|c|c|c|c|c|c|}
\hline S/N & Questions & \multicolumn{2}{c|}{$\begin{array}{c}\text { Total } \\
\text { Responses }\end{array}$} & \multicolumn{2}{c|}{$\begin{array}{c}\text { Percentage } \\
\text { Responses }\end{array}$} \\
\cline { 3 - 6 } & & Yes & No & \% Yes & \%No \\
\hline 1 & $\begin{array}{c}\text { Do you agree that everybody in this area is seriously } \\
\text { watching to protect the power facility in this area? }\end{array}$ & 33 & 17 & 66 & 34 \\
\hline 2 & $\begin{array}{c}\text { In this community, do we have private Vigilante group } \\
\text { protecting the power facilities? }\end{array}$ & 14 & 36 & 28 & 72 \\
\hline 3 & $\begin{array}{c}\text { Can you support and contribute in paying the vigilante } \\
\text { protecting power facilities in your community? }\end{array}$ & 33 & 16 & 66 & 34 \\
\hline 4 & $\begin{array}{c}\text { Do you agree that the jobless in this community are } \\
\text { willing to be volunteers protecting power facilities? }\end{array}$ & 25 & 25 & 50 & 50 \\
\hline 5 & $\begin{array}{c}\text { Has this community ever repair and maintain power } \\
\text { facility on behalf of the Power Company? }\end{array}$ & 39 & 11 & 78 & 22 \\
\hline 6 & $\begin{array}{c}\text { Will you agree to volunteer information to expose } \\
\text { security threats to power facilities? }\end{array}$ & 43 & 7 & 86 & 14 \\
\hline & \multicolumn{2}{|c|}{ Aggregate percentage in support } & $\mathbf{6 2 . 3 3}$ & \\
\hline
\end{tabular}

Source: Field survey 2018

From the table values above in 4.3.2, it showed that $66 \%$ of the FCT people are sensitive to the safety of power facility and equal numbers of people are ready to contribute to financing the issue of private security guard on the equipment. Low percentage of power consumers up to $28 \%$ are ready to contribute to better the functionality of power facilities while many prefer a more serious community guard to earn their support. It was equally revealed from the graph 4:3:2 below that $50 \%$ of FCT members supported the idea of employing the jobless in their community to guard the vulnerable power facilities. The study showed that $86 \%$ are prepared to volunteer information to expose security threat to power facilities.

Deduction from the above analysis showed that in total the FCT community people preparedness to support the protection of power facilities in their domain is as high as $62.33 \%$.

Graph 4.3.2 Community protection support level in FCT

\begin{tabular}{|c|c|c|c|}
\hline S/N & A & B \% & C\% \\
\hline 1 & $\begin{array}{c}\text { Customers' readiness to guard power } \\
\text { facilities }\end{array}$ & 66 & 34 \\
\hline 2 & Presence of private security & 28 & 72 \\
\hline 3 & Customers' in supporters of private security & 66 & 34 \\
\hline 4 & $\begin{array}{c}\text { Engaging the jobless in the community } \\
\text { policing }\end{array}$ & 50 & 50 \\
\hline 5 & $\begin{array}{c}\text { Community sponsored repairs on power } \\
\text { facilities }\end{array}$ & 78 & 22 \\
\hline 6 & $\begin{array}{c}\text { Customers' willingness to volunteer } \\
\text { information. }\end{array}$ & 86 & 14 \\
\hline
\end{tabular}


Customers' willingness to volunteer information.

Community sponsored repairs on power facilities

Engaging the jobless in the community policing

Customers' in supporters of private security

Presence of private security

Customers' readiness to guard power facilities

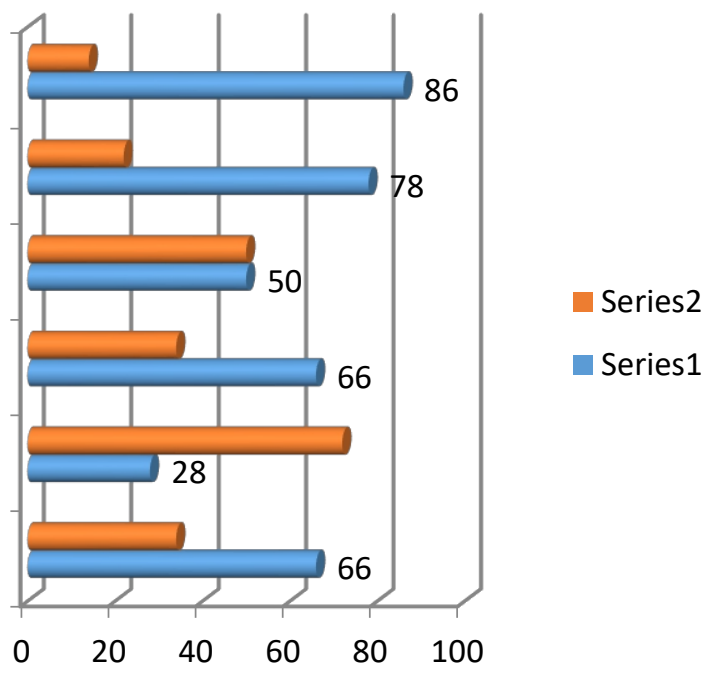

\section{Research Question Three}

How much support do the staff of electricity Power Company offer to the protection of power facilities in FCT?

Table 4.3.3

\begin{tabular}{|c|c|c|c|c|c|}
\hline \multirow[t]{2}{*}{$\mathbf{S} / \mathbf{N}$} & \multirow[t]{2}{*}{ Questions } & \multicolumn{2}{|c|}{$\begin{array}{c}\text { Total } \\
\text { Responses }\end{array}$} & \multicolumn{2}{|c|}{$\begin{array}{l}\text { Percentage } \\
\text { Responses }\end{array}$} \\
\hline & & Yes & No & $\%$ Yes & $\% \mathrm{No}$ \\
\hline 1 & $\begin{array}{l}\text { Do you agree that security experts of this company has } \\
\text { robust protection plan against internal and external } \\
\text { vandalism? }\end{array}$ & 22 & 25 & 46.81 & 53.19 \\
\hline 2 & $\begin{array}{l}\text { Do you agree that power company staffs' are } \\
\text { committed to protect the company facilities? }\end{array}$ & 21 & 28 & 42.86 & 57.14 \\
\hline 3 & $\begin{array}{l}\text { Do you agree that staffs of power companies } \\
\text { compromise to sabotage and benefit themselves? }\end{array}$ & 36 & 13 & 73.47 & 26.53 \\
\hline 4 & $\begin{array}{l}\text { Do you agree that power facility staff uses substandard } \\
\text { spare parts to cut corners which endangers protection? }\end{array}$ & 24 & 24 & 50.00 & 50.00 \\
\hline 5 & $\begin{array}{l}\text { Is the power facility endangered when } \\
\text { Distribution Company demand payment } \\
\text { for energy it did not evacuate to the } \\
\text { customers? }\end{array}$ & 33 & 17 & 66.00 & 34.00 \\
\hline 6 & $\begin{array}{c}\text { As a staff and a consumer of electricity, would you } \\
\text { agree that staffs of power companies are faithful } \\
\text { ambassadors? }\end{array}$ & 9 & 40 & 22.50 & 77.50 \\
\hline & Aggregate percentage in support & & & 50.27 & \\
\hline
\end{tabular}

Source: Field survey 2018 
As revealed from the responses in table 4.3.3 and subsequently the corresponding graphical representation below, it has been shown that $46.81 \%$ recorded was an indication that Power Company security experts in FCT do not have up to half of what it takes for a robust protection plan against internal and external aggressions. There is high value of $73.47 \%$ showing the compromise level of Power Company staffs and that their commitment to work is $26.53 \%$.

The deduction from the above showed that the staffs of electricity Power Company can only offer $50.2 \%$ to support their employer in protecting power facilities.

\begin{tabular}{|c|c|c|c|}
\multicolumn{4}{c}{ Graph 4.3.3 $\quad$ Staff commitment to protection of power facil } \\
\hline S/N & A & B \% & C \% \\
\hline 1 & $\begin{array}{c}\text { Staff's understanding of safety of } \\
\text { Power facilities }\end{array}$ & 46.81 & 53.19 \\
\hline 2 & $\begin{array}{c}\text { Staff's commitment to protect } \\
\text { Power facilities }\end{array}$ & 42.86 & 57.14 \\
\hline 3 & $\begin{array}{c}\text { Staff's compromise on safety of } \\
\text { Power facilities }\end{array}$ & 73.47 & 26.53 \\
\hline 4 & $\begin{array}{c}\text { Staff's usage of substandard } \\
\text { materials for repairs. }\end{array}$ & 50 & 50 \\
\hline 5 & $\begin{array}{c}\text { Level of danger when customers' } \\
\text { are over charged }\end{array}$ & 66 & 34 \\
\hline 6 & $\begin{array}{r}\text { Poor perception about Power } \\
\text { Company's staff }\end{array}$ & 22.5 & 77.5 \\
\hline
\end{tabular}

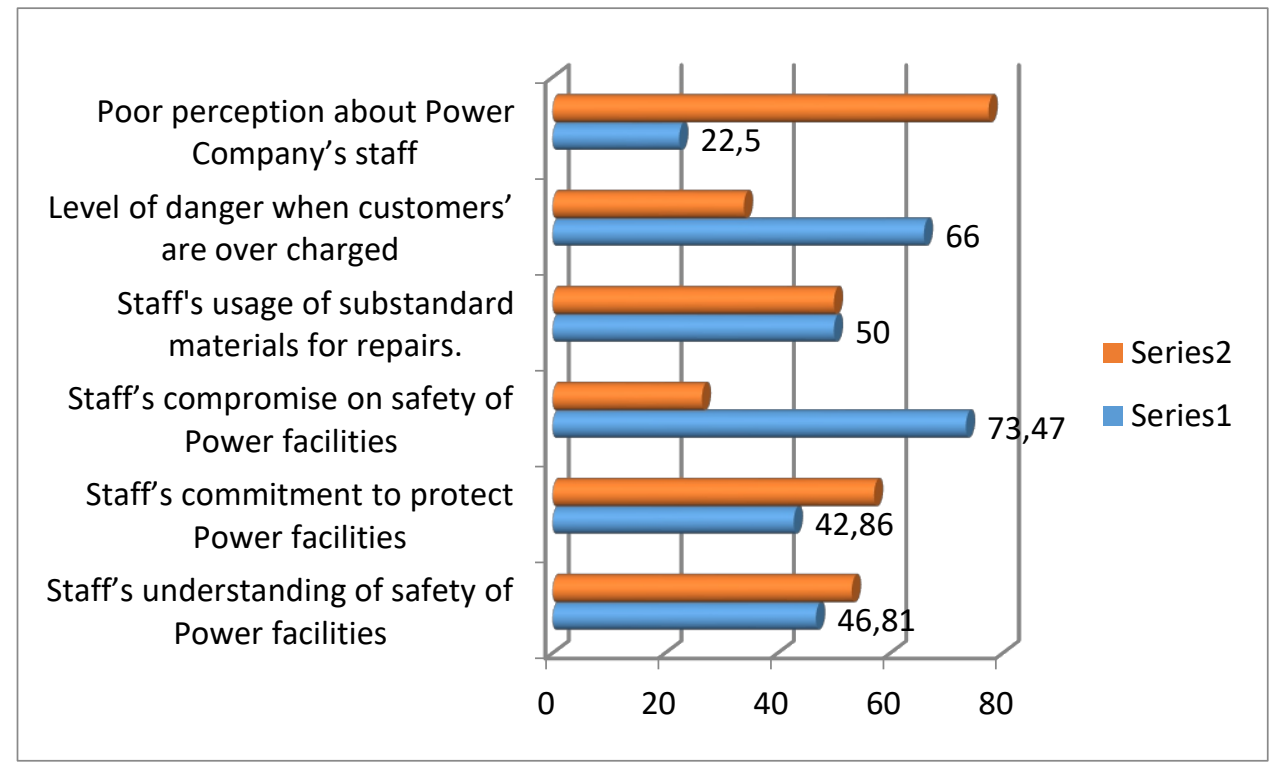




\section{Research Question Four}

Are the court verdicts, laws and terms of convictions helpful in curtailing attacks on power facilities in FCT?

Table 4.3.4

Effects of Court verdicts in power facility protection

\begin{tabular}{|c|c|c|c|c|c|}
\hline \multirow[t]{2}{*}{$\mathbf{S} / \mathbf{N}$} & \multirow[t]{2}{*}{ Questions } & \multicolumn{2}{|c|}{$\begin{array}{c}\text { Total } \\
\text { Responses }\end{array}$} & \multicolumn{2}{|c|}{$\begin{array}{l}\text { Percentage } \\
\text { Responses }\end{array}$} \\
\hline & & Yes & No & $\begin{array}{c}\% \\
\text { Yes }\end{array}$ & $\% \mathrm{No}$ \\
\hline 1 & $\begin{array}{l}\text { Do you agree that the existing court verdicts on } \\
\text { vandalism adequately match the gravity of the crime } \\
\text { committed? }\end{array}$ & 17 & 33 & 34.00 & 66.00 \\
\hline 2 & $\begin{array}{c}\text { Do you agree that lack of speedy trial of cases of } \\
\text { damages to power facilities undermines protection of } \\
\text { power facilities? }\end{array}$ & 33 & 17 & 66.00 & 34.00 \\
\hline 3 & $\begin{array}{l}\text { Do you agree that it is always difficult getting high courts } \\
\text { judges assigned to vandalism cases? }\end{array}$ & 19 & 30 & 38.78 & 61.22 \\
\hline 4 & $\begin{array}{l}\text { Do you agree that possession of copper should be } \\
\text { regarded as criminal offence just to protect copper } \\
\text { material on power facilities? }\end{array}$ & 35 & 15 & 70.00 & 30.00 \\
\hline 5 & $\begin{array}{l}\text { The options of fine on vandalism cases are truly } \\
\text { meagre; do you agree that this penalty should be } \\
\text { amended? }\end{array}$ & 45 & 5 & 90.00 & 10.00 \\
\hline 6 & $\begin{array}{l}\text { Do you agree that stiffer penalty verdicts can } \\
\text { discourage further attack on power facilities? }\end{array}$ & 48 & 2 & 96.00 & 4.00 \\
\hline & Aggregate percentage in support & & & 60.46 & \\
\hline
\end{tabular}

Source: Field survey 2018

In the table 4.3.4 as shown above, the low value of $34 \%$ indicated level of insignificance of court verdicts in curbing damages and vandalism on power facilities around FCT Abuja. Many respondents up to $66 \%$ were of the opinion that accelerated court trial if applied against vandals is a better antidote to vandalism on power facilities but the chance of getting high court judge is as slim as $38.78 \%$. High percentage of $70 \%$ from the respondents agreed with the court to criminalize possession of copper material and that option of fine in court cases should be made tougher with a vote of $90 \%$ if at all it cannot be abrogated.

In conclusion, it can be deduced that with the average value of $60.46 \%$ for existing court verdicts, laws and terms of convictions are achieving the desired result of curtailing attacks on power facilities in FCT 
Graph 4.3.4 Effects of Court verdicts in power facility protection

\begin{tabular}{|c|c|c|c|}
\hline S/N & A & B \% & C \% \\
\hline 1 & $\begin{array}{c}\text { Existing court verdicts not curbing } \\
\text { vandalism on power facilities }\end{array}$ & 34 & 66 \\
\hline 2 & $\begin{array}{c}\text { Lack of speedy court trials } \\
\text { undermines power facility } \\
\text { protection. }\end{array}$ & 66 & 34 \\
\hline 3 & $\begin{array}{c}\text { Few agreed to difficulty in getting } \\
\text { courts judges for vandalism cases }\end{array}$ & 38.8 & 61.22 \\
\hline 4 & $\begin{array}{c}\text { Criminalizing the possession of } \\
\text { copper materials }\end{array}$ & 70 & 30 \\
\hline 5 & $\begin{array}{c}\text { Many supported amendment to court } \\
\text { option of fine }\end{array}$ & 90 & 10 \\
\hline 6 & $\begin{array}{c}\text { High level support for stiffer penalty } \\
\text { on damages to power facilities }\end{array}$ & 96 & 4 \\
\hline
\end{tabular}

High level support for stiffer penalty on damages to power...

Many supported amendment to court option of fine

Criminalizing the possession of copper materials

Few agreed to difficulty in getting courts judges for vandalism cases

Lack of speedy court trials undermines power facility...

Existing court verdicts not curbing vandalism on power facilities

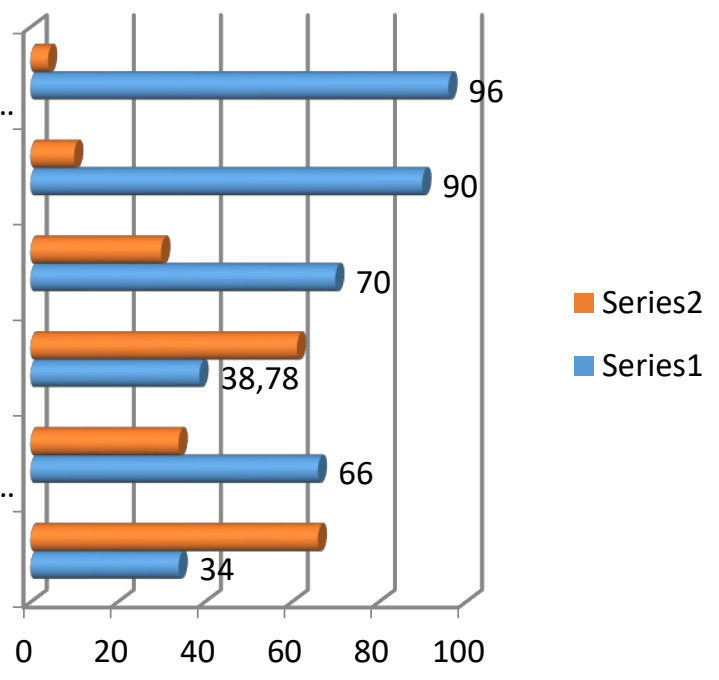

\section{Research Question Five}

What is the level of preparedness of security personnel to mitigate the effects of attacks on power facilities in FCT? 
Table 4.3.5

Effects of optimum provision of tools of trade in power facility protections.

\begin{tabular}{|c|c|c|c|c|c|}
\hline \multirow[t]{2}{*}{$\mathbf{S} / \mathbf{N}$} & \multirow[t]{2}{*}{ Questions } & \multicolumn{2}{|c|}{$\begin{array}{c}\text { Total } \\
\text { Responses }\end{array}$} & \multicolumn{2}{|c|}{$\begin{array}{l}\text { Percentage } \\
\text { Responses }\end{array}$} \\
\hline & & Yes & No & $\begin{array}{c}\% \\
\text { Yes }\end{array}$ & $\%$ No \\
\hline 1 & $\begin{array}{l}\text { Do you think the presence of armed personnel reduces } \\
\text { attack on power facilities? }\end{array}$ & 39 & 11 & 78.00 & 22.00 \\
\hline 2 & $\begin{array}{l}\text { Do you agree that security officers respond fast to } \\
\text { attacks on power facilities? }\end{array}$ & 27 & 23 & 54.00 & 46.00 \\
\hline 3 & $\begin{array}{l}\text { Do you agree that the security personnel on power } \\
\text { facilities are motivated to excel in their profession? }\end{array}$ & 11 & 39 & 22.44 & 77.56 \\
\hline 4 & $\begin{array}{l}\text { Is the government adequately funding security } \\
\text { personnel to protect power facilities as expected? }\end{array}$ & 17 & 32 & 34.69 & 65.31 \\
\hline 5 & $\begin{array}{l}\text { Security officers' primary duty is to protect, do } \\
\text { you agree that the Power Company should be } \\
\text { responsive to officers' welfare packages? }\end{array}$ & 45 & 5 & 90.00 & 10.00 \\
\hline 6 & $\begin{array}{l}\text { Do you agree that power company should provide } \\
\text { security officer with tools of trade to perform their } \\
\text { statutory duty? }\end{array}$ & 41 & 9 & 82.00 & 18.00 \\
\hline & Aggregate percentage in support & & & 60.19 & \\
\hline
\end{tabular}

Source: Field survey 2018

The table 4.3.5 above as well as the graphical representation below was gotten from power facility protected zone in FCT and it showed a high value of $78 \%$ in favour of reduction of attacks on facilities owing to the presence of security personnel. Also 54\% showed that security personnel response was slightly above average but the low percentage of $22.44 \%$ showed that they are not adequately motivated to excel in their profession. Similarly the low percentage value of $34.69 \%$ showed that the government funding is far below average.

It was observed that many respondents in FCT up to $82 \%$ maintained that Power companies should be responsive to welfare packages of the security personnel on their facility protection.

The deduction from above showed that the level of preparedness of security personnel to mitigate the effects of attacks on power facilities in FCT is about $60.19 \%$. 
Graph 4.3.5 Effects of optimum provision of tools of trade in power facility protections.

\begin{tabular}{|c|c|c|c|}
\hline S/N & A & B \% & C \% \\
\hline 1 & $\begin{array}{c}\text { Presence of armed personnel } \\
\text { reduces attack on power facilities. }\end{array}$ & 78 & 22 \\
\hline 2 & $\begin{array}{c}\text { Speed of response of security to } \\
\text { attacks on power facilities. }\end{array}$ & 54 & 46 \\
\hline 3 & $\begin{array}{c}\text { Low level of motivation for } \\
\text { security personnel on their } \\
\text { profession. }\end{array}$ & 22.44 & 77.56 \\
\hline 5 & $\begin{array}{c}\text { Government funding inadequate for } \\
\text { security to protect power facilities. }\end{array}$ & 34.69 & 65.31 \\
\hline 5 & $\begin{array}{c}\text { Customers charged Power } \\
\text { Company to be responsive to } \\
\text { officers' welfare }\end{array}$ & 90 & 10 \\
\hline 6 & $\begin{array}{c}\text { Many prefer power company to } \\
\text { supply tools of trade to security. }\end{array}$ & 82 & 18 \\
\hline
\end{tabular}

Many prefer power company to supply tools of trade to security.

Customers charged Power

Company to be responsive to...

Government funding inadequate for security to protect power...

Low level of motivation for security personnel on their...

Speed of response of security to attacks on power facilities.

Presence of armed personnel reduces attack on power...

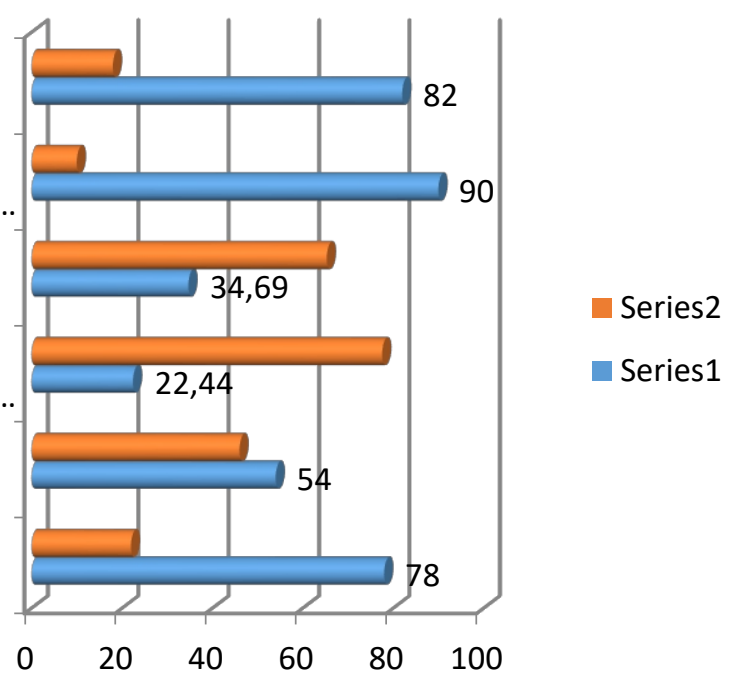

\section{Research Question Six}

How effective is the existing vandalism protection technique on the power transmission network facilities within FCT? 
Table 4.3.6

Response on protection technique of Transmission Company in FCT

\begin{tabular}{|c|c|c|c|c|c|}
\hline S/N & Questions & \multicolumn{2}{c|}{$\begin{array}{c}\text { Total } \\
\text { Responses }\end{array}$} & \multicolumn{2}{c|}{$\begin{array}{c}\text { Percentage } \\
\text { Responses }\end{array}$} \\
\cline { 3 - 6 } & Yes & No & $\begin{array}{c}\text { \% } \\
\text { Yes }\end{array}$ & \% No \\
\hline 1 & $\begin{array}{c}\text { Do you agree that Transmission Company of Nigeria } \\
\text { (TCN) has a strong protection plan against vandalism? }\end{array}$ & 17 & 33 & 34.00 & 66.00 \\
\hline 2 & $\begin{array}{c}\text { Does the TCN engage armed security personnel to } \\
\text { guard its transmission network? }\end{array}$ & 38 & 11 & 76.00 & 24.00 \\
\hline 3 & $\begin{array}{c}\text { Do you know if TCN is involving community people } \\
\text { in its power protection awareness? }\end{array}$ & 18 & 32 & 36.00 & 64.00 \\
\hline 4 & $\begin{array}{c}\text { Do you agree that network surveillance for } \\
\text { maintenance is protecting the grid? }\end{array}$ & 21 & 28 & 42.86 & 57.14 \\
\hline 5 & $\begin{array}{c}\text { Do you think the management of TCN should } \\
\text { therefore be responsible for the welfare of armed } \\
\text { personnel deployed to their network? }\end{array}$ & 47 & 3 & 94.00 & 6.00 \\
\hline 6 & $\begin{array}{c}\text { Do you agree that transmission of power has ever been } \\
\text { sabotage for political reasons? }\end{array}$ & 36 & 14 & 73.46 & 26.54 \\
\hline & \multicolumn{2}{|c|}{ Aggregate percentage in support } & & 59.39 & \\
\hline
\end{tabular}

Source: Field survey 2018

Using the above table 4.3.6 and the corresponding graphical representation below for interpretation therefore, TCN protection strategy scored a low value of $34 \%$ rating despite the fact that the presence of armed personnel is as high as 76\% on the facilities in FCT. The table equally gives a low value of $36 \%$ on the involvement of the community people in TCN protection strategy. Similarly a slightly below average percentage value of $42.86 \%$ on surveillance for maintenance was recorded with high level percentage of $73.46 \%$ for non-fading sabotage. Finally, the high percentage value of $94 \%$ is in support of Transmission Company to be responsive to security matters.

In conclusion, the existing vandalism protection technique on the power transmission network facilities within FCT is on the average value of $59.39 \%$ but not the best for a nation hoping to stabilize energy sector.

Graph 4.3.6 Response on protection technique of Transmission Company in FCT

\begin{tabular}{|c|c|c|c|}
\hline S/N & A & B\% & C\% \\
\hline 1 & $\begin{array}{c}\text { TCN protection plan against } \\
\text { vandalism not robust }\end{array}$ & 34 & 66 \\
\hline 2 & $\begin{array}{c}\text { TCN tipped to be responsible for the } \\
\text { welfare of armed personnel. }\end{array}$ & 76 & 24 \\
\hline 3 & $\begin{array}{c}\text { High security presence on TCN } \\
\text { facilities }\end{array}$ & 36 & 64 \\
\hline 4 & $\begin{array}{c}\text { Low public involvement in TCN } \\
\text { protection plan in FCT }\end{array}$ & 42.86 & 57.14 \\
\hline 5 & $\begin{array}{c}\text { Surveillance for maintenance below } \\
\text { average }\end{array}$ & 94 & 6 \\
\hline 6 & $\begin{array}{c}\text { High level of sabotage in protection } \\
\text { plan. }\end{array}$ & 73.46 & 26.54 \\
\hline
\end{tabular}




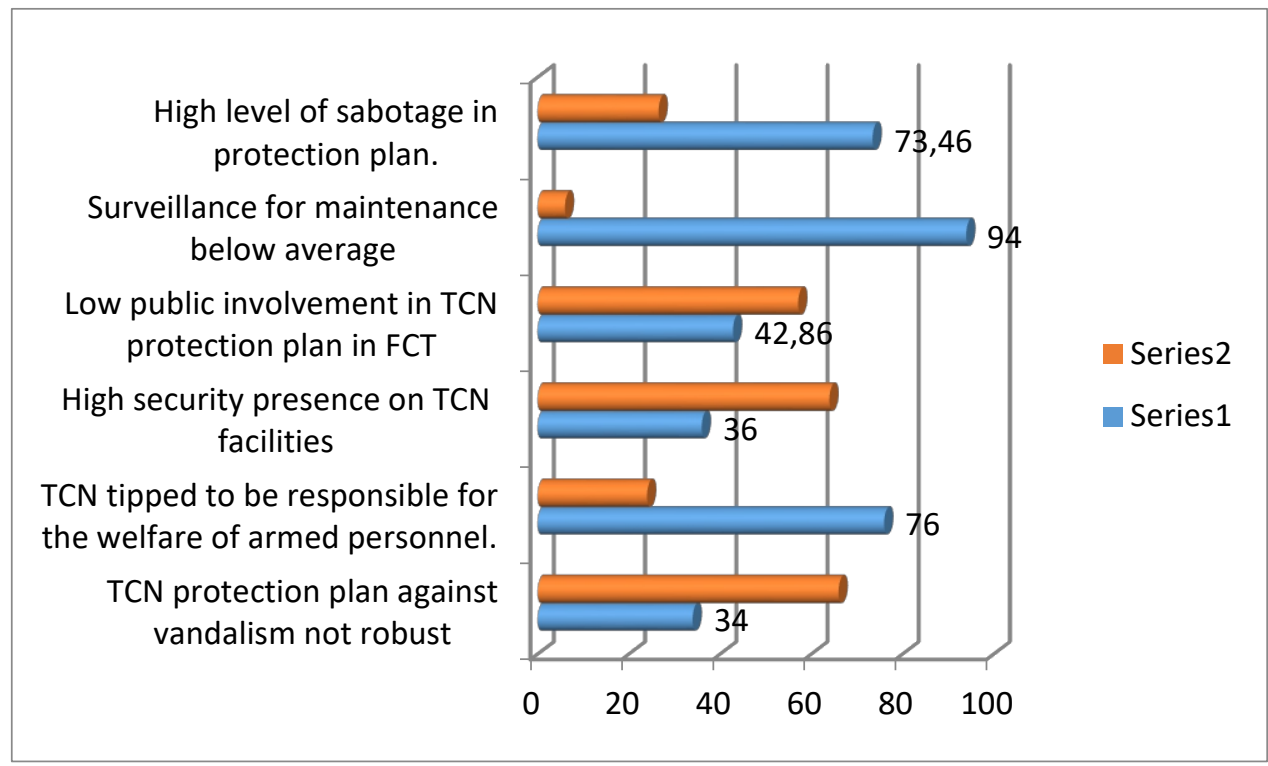

\section{Discussion and Implication of Findings}

This study revealed the presence of modest protection technique around power facilities like transformer, transformer substations, distribution network and Injection substations in FCT, but proving this inadequacy is beyond the scope of this research work. The study also made it known that the FCT community people are prepared to support the protection of power facilities in their domain, they are fully prepared to mitigate the effects of attacks on power facilities and in support of the idea of stiffer court penalties against all forms of damages to power facilities. The study further revealed that the existing vandalism protection technique on the power transmission network facilities within FCT is meek, unassertive and far below average for relying much on government and benevolence of the community and little from the company's staff. In conclusion, if we win in our mission to protect power facilities, then our growth will be certain!

\section{Recommendations}

This research work investigated the effectiveness of protection of critical infrastructure in Nigeria; with special reference to the protection of power facilities in Federal Capital Territory (FCT) Abuja. The study recommended equipment/system as well as policy strategic techniques in protection of power facilities. The recommended policies on strategy techniques included stiffer penalty verdicts with reference to abrogation of option of fines and criminalizing the possession of copper material. This is achievable by lobbing for amendment of these laws to prevent intentional and accidental damages to power facilities in FCT. Other policies under this category are the establishment of community anti-crime group (Phillip, Lewis and Todd 2005) 
and provision of free toll hotline for emergency purposes. The combination of government security with community anti-crime group is achievable if government and the company can coordinate the relevant stake holders. Provision of functional electronic surveillance monitoring gadgets and Transformer Risk Management Insurance scheme is another policy strategy worthy of consideration. On equipment and system strategy policy, the study recommended that high capacity distribution transformers covering larger area should be replaced with numerous smaller pole mounted power transformers with a view to making vandals' access to it difficult and also that attacks on these transformers would become localized since resulting power outage would be limited to a smaller area.

\section{References:}

1. Badiora and Obadiora (2011). 'Graffiti vandalism of Public Facilities in schools and Colleges :International Journal of Development Studies Vol. 2 No. 3

2. Caleta and Shemella (2011). Counter-Terrorism challenges regarding the process of critical infrastructure protection.

3. David J.J (2011) Crime Prevention Through Environmental Design.

4. Kothari C.R (2004).-Research Methodology, methods and Techniques.

5. Janes (2014) "Adopting a holistic approach to Protecting Critical Infrastructure. (http://www.janes.com/article/39495/adopting-aholistic-approach-to- protecting-critical-infrastructure-es14e3. )

6. Laurence W. Z (2001).Protecting infrastructure against attack.

7. Lucas and Leonardo (2014) Critical Infrastructure Protection: Threats, Attacks and Countermeasures.

8. National Bureau of Statistics (NBS) Annual Abstract of Statistics, Abuja

9. Ola, A.B (2010). Infrastructural Vandalism in Nigerian Cities: The Case of Osogbo, Osun State.

10. Paulsen and Robinson (2004). 'Eyes on the Street'

11. Phillip, Lewis, Todd and Erwann (2005). The Challenge of Protecting Critical Infrastructure.

\section{Retrieval online links:}

12. https://ec.europa.eu/home-affairs/what-we-do/policies/crisis-andterrorism/critical-infrastructure. Retrieved on $4^{\text {th }}$ March 2018

13. www.oecd.org/daf/investment/statistics. Retrieved on $19^{\text {th }}$ March $\underline{2018 .}$ 